\title{
Properties of Fructose-1,6-bisphosphatase from Carp, Eel and Rainbow Trout Liver
}

\author{
Koji Nagashima, ${ }^{* 1}$ Takayuki Nakagawa, ${ }^{* 1,2}$ and Fumio Nagayama*1 \\ (Received November 25, 1988)
}

\begin{abstract}
Fructose-1, 6-bisphosphatase (EC 3.1.3.11) from rainbow trout liver, eel liver, and carp hepatopancreas was purified by ammonium sulfate fractionation, followed by phosphocellulose column chromatography, and Sephadex G-200 gel filtration. Specific activity of the rainbow trout enzyme was comparable to that of the eel enzyme, while the carp enzyme was about one fifth of the above two fish species. Maximal activity of the enzyme was found around pH 7.4, irrespective of fish species. The $\mathrm{Km}$ values of the rainbow trout, eel and carp enzymes for FBP were $5.6,8.2$, and $12.5 \mu \mathrm{M}$, respectively. Fish enzyme required $\mathrm{Mg}^{2+}$ for activation. In the case of carp enzyme, $\mathrm{Mn}^{2+}$ was also effective for activation. The activation constants for $\mathrm{Mg}^{2+}$ and $\mathrm{Mn}^{2+}$ ranged from 1 to $10 \mathrm{~mm}$ and from 0.2 to $0.3 \mathrm{~mm}$, respectively. The activities of the rainbow trout and eel enzymes were further activated by the addition of $\mathrm{K}^{+}$and $\mathrm{NH}_{4}{ }^{+}$in the presence of $\mathrm{Mg}^{2+}$ whereas both monovalent cations inhibited carp enzyme. $\mathrm{Na}^{+}$inhibited the activity of the fish enzyme in the presence of $\mathrm{Mg}^{2+}$. AMP stroungly inhibited the enzyme activity. In the presence of $1 \mathrm{mM} \mathrm{AMP}$ and $0.5 \mathrm{mM} \mathrm{Mg}^{2+}$ at $\mathrm{pH} 7.5$, the enzymatic activity was inhibited by $57 \%$ in rainbow trout, $100 \%$ in eel, and $65 \%$ in carp.
\end{abstract}

Fructose-1, 6-bisphosphatase (D - fructose - 1, 6bisphsosphate 1-phosphohydrolase, EC 3.1.3.11, FBPase) has been described as one of the key, rate-limiting enzymes in gluconeogenesis. ${ }^{12}$ FBPase has been investigated in numerous biological sources such as liver, ${ }^{2-7)}$ kidney, ${ }^{87}$ and muscle. ${ }^{3,8)}$ In view of the regulation of its catalytic activity, it is of interest to clarify its inhibition by either FBP or AMP or both. ${ }^{2)}$

Extensive studies of the fish enzyme have been performed using crude extracts and there is limited information on the properties of purified fish enzyme. ${ }^{10-14}$ Moreover, some regulating factors affecting the enzyme activity such as substrate concentration, coenzymes, and metal ions should be investigated.

As a series of studies on the mechanism of carbohydrate metabolism in fish liver, our previous report has characterized liver phosphofructokinase from rainbow trout, eel and carp, and revealed a marked species-specificity. ${ }^{15)}$ To clarify further the mechanism of carbohydrate metabolism in fish liver, we purified FBPase from rainbow trout, eel and carp in the present study, and examined their enzymatic properties.

\section{Materials and Methods}

\section{Materials}

Live specimens of rainbow trout Salmo gairdnerii, eel Angulla japonica, and carp Cyprinus carpio were purchased from a commercial market. The acetone-dried powder of liver or hepatopancrease was prepared following the method of Pontremoli, ${ }^{4)}$ and was kept at $-20^{\circ} \mathrm{C}$.

\section{FBPase Assay}

FBPase activity was measured at $25^{\circ} \mathrm{C}$ according to the method of Pontremolit) by monitoring the rate of reduction of $\mathrm{NADP}^{+}$at $340 \mathrm{~nm}$. For the routine assay, the reaction mixture contained $50 \mathrm{~mm}$ triethanolamine- $\mathrm{HCl}$ buffer ( $\mathrm{pH} 7.5), 5 \mathrm{~mm}$ $\mathrm{MgCl}_{2}, 1.4$ units glucosepahosphate isomerase, 0.7 units glucose-6-phosphate dehydrogenase, 0.25 mM fructose-1, 6-bisphosphate (FBP), $0.25 \mathrm{~mm}$ $\mathrm{NADP}^{+}$. The reaction was started by the addition of the enzyme solution to the above mixture $(0.6 \mathrm{~m} /$ in final volume). One unit of enzyme was defined as the amount which converts $1 \mu$ mol of FBP to fructose-6-phosphate (F6P) per min under the assay condition.

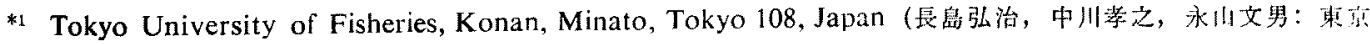
水産大学).

*2 Present address: Faculty of Agriculture, Kinki University, Naka-machi, Nara 631, Japan (近畿大学 学部). 


\section{Purification of FBPase}

All purification steps were carried out at 0 $4^{\circ} \mathrm{C}$. The acetone-dried powder was extracted with 5 volumes of $20 \mathrm{~mm}$ Tris- $\mathrm{HCl}$ buffer $(\mathrm{pH} 7.5)$ containing $2 \mathrm{~mm}$ EDTA under gentle stirring for $60 \mathrm{~min}$. The suspension was centrifuged for $60 \mathrm{~min}$ at $25,000 \times \mathrm{g}$. To the supernatant was added solid ammonium sulfate to bring it to $30 \%$ saturation. After $30 \mathrm{~min}$, the precipitate was removed by centrifugation at $10,000 \times \mathrm{g}$ for 20 min. The supernatant obtained was again treated with solid ammonium sulfate in the same manner described above. The precipitate at $70 \%$ saturation was collected by centrifugation, dissolved in a small volume of $10 \mathrm{mM}$ Tris- $\mathrm{HCl}$ buffer ( $\mathrm{pH}$ 7.5) containing $1 \mathrm{~mm}$ EDTA (buffer A), and was dialyzed overnight against buffer $A$. The dialyzed enzyme solution was applied to a phosphocellulose column $(3.1 \times 24 \mathrm{~cm})$ equilibrated with buffer $A$. The adsorbed enzyme was eluted with a linear gradient of $\mathrm{KCl}$ from 0 to $0.75 \mathrm{M}$, in a total volume of $400 \mathrm{~m} l$ of buffer A. The active fractions from rainbow trout and eel were further purified by gel filtration as in the following procedure: The pooled enzyme solution was concentrated by ultrafiltration. The concentrated enzyme solution was applied to a Sephadex G-200 column $(2.5 \times 32 \mathrm{~cm})$ equilibrated with $50 \mathrm{~mm}$ Tris- $\mathrm{HCl}$ buffer ( $\mathrm{pH} 7.5$ ) containing $1 \mathrm{mM}$ EDTA (buffer $\mathrm{B}$ ), and the proteins were eluted with buffer $\mathbf{B}$.

\section{Results and Discussion}

As shown in Table 1, FBPase activity in the crude extract of the carp hepatopancreas was lower than that of the trout and eel livers. As reported previously, ${ }^{15)}$ the distribution pattern of phosphofructokinase in fish liver showed the contrary for FBPase. Shimeno ${ }^{14}$ observed that FBPase activity of omnivorous fish such as carp and crucian carp is lower than that of carnivorous fish such as yellowtail and spotted mackerel. The

Table 1. Activities and specific activities of fructose1,6 -bisphosphatase in fish liver extracts

\begin{tabular}{lcc}
\hline Species & $\begin{array}{c}\text { Activity } \\
(\mu \mathrm{mol} / \mathrm{min} \cdot g \\
\text { tissue) }\end{array}$ & $\begin{array}{c}\text { Specific activity } \\
(\mu \mathrm{mol} / \mathrm{min} \cdot \mathrm{mg} \\
\text { protein })\end{array}$ \\
\hline Rainbow trout & $3.2 \times 10^{-3}$ & 0.09 \\
Eel & $3.3 \times 10^{-3}$ & 0.12 \\
Carp & $1.5 \times 10^{-3}$ & 0.02 \\
\hline
\end{tabular}

Activity was measured in the presence of $0.25 \mathrm{mM} F B P$ and $5 \mathrm{~mm}$ $\mathrm{Mg}^{2+}$ at $\mathrm{pH} 7.5$ and $25^{\circ} \mathrm{C}$. present results might be attributed to the food habit of fish rather than to its location. Specific activities of the rainbow trout and eel enzymes showed the same levels as that of rat ${ }^{4)}$ and bovine ${ }^{6)}$ enzymes.

FBPase activity was eluted as single peak from the phosphocellulose column at the $\mathrm{KCl}$ concentration of around $0.5 \mathrm{M}$ for rainbow trout and eel, and at $0.75 \mathrm{M}$ for carp, respectively (Fig. 1). Olson and Marquardt ${ }^{3)}$ eluted FBPase of chicken breast muscle from the phosphocel-
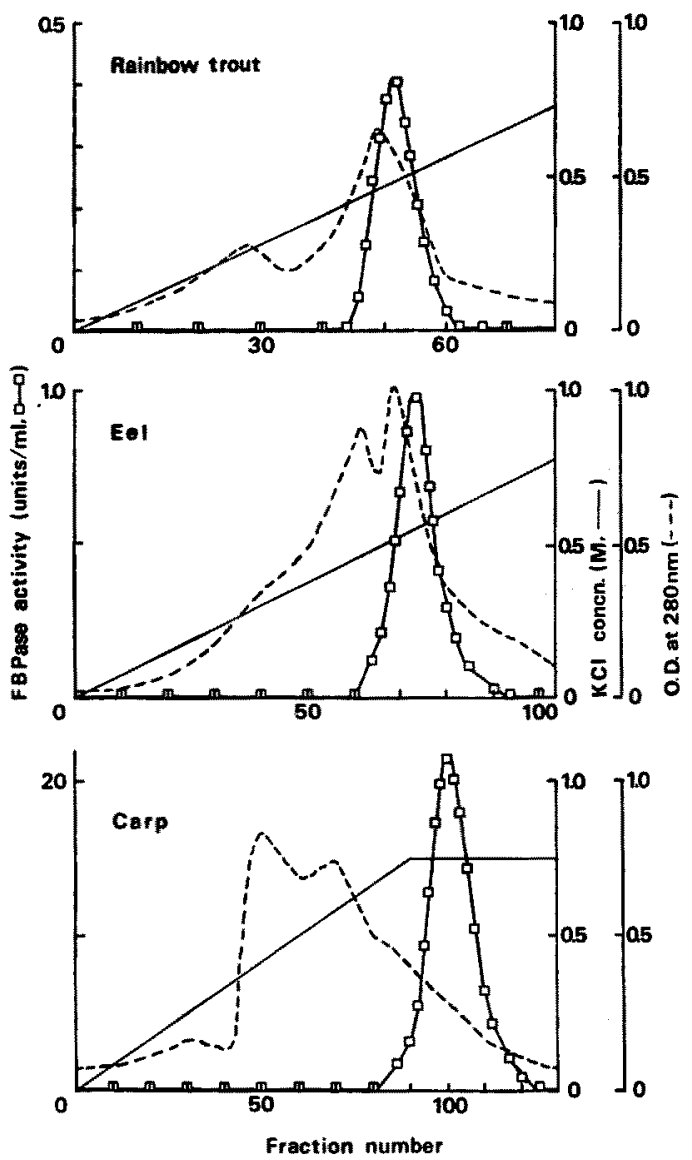

Fig. 1. Phosphocellulose column chromatography of the rainbow trout, eel, and carp liver fructose1, 6-bisphosphatase. The precipitate by ammonium sulfate fractionations $(30-70 \%$ saturation) was dissolved in and dialyzed against $10 \mathrm{~mm}$ Tris-HCl buffer ( $\mathrm{pH} \mathrm{7.5)} \mathrm{containing} 1 \mathrm{~mm}$ EDTA, then applied to a phosphocellulose column $(3.1 \times 24 \mathrm{~cm})$ equilibrated with the same buffer. Elution was carried out with a linear gradient of $\mathrm{KCl}$ from 0 to $0.75 \mathrm{M}$ in a total volume of $400 \mathrm{ml}$ of the above buffer. Fractions of $5 \mathrm{~m} l$ were collected. 
lulose column at $0.4 \mathrm{M} \mathrm{KCl}$. The carp enzyme preparation eluted from the phosphocellulose column showed some contaminations. Their further purification was discontinued due to the scarcity of the available sample. The rainbow trout and eel enzymes were further purified by Sephadex G-200 gel filtration, and FBPase activity from both species was detected as single peak (data not shown). The estimated molecular weight of fish FBPase of about 145,000 by Sephadex G-200 gel filtration is close to the value obtained for beef $(130,000),{ }^{53}$ rabbit $(130,000-140,000),{ }^{8)}$ and chicken $(140,000)^{\tau)}$ liver enzymes.

FBPase exhibited maximal activity at pH 7.4, irrespective of fish species (data not shown). FBPase activity was not detected at $\mathrm{pH}$ values below 6 , whereas $60-80 \%$ of maximal activity was detected above $\mathrm{pH}$ 8. Shimeno ${ }^{14)}$ determined the optimum $\mathrm{pH}$ of the spotted mackerel liver enzyme to be around 7. Rainbow trout ${ }^{10)}$ and salmon $^{12)}$ enzymes, on the other hand, showed maximal activity at $\mathrm{pH} 9.5$ in the presence of $\mathrm{Mg}^{2+}$ as activator. It is generally accepted that "neutral FBPase" having maximal activity at a $\mathrm{pH}$ range between 7.0 and 7.5 is a physiological enzyme. $\left.{ }^{8}, 16\right)$ Nakashima and Horecker ${ }^{10)}$ reported that "alkaline FBPase" was induced by the action of internal proteinase during heat treatment or acetone fractionation in the purification process. In order to clarify the effect of acetone treatment on the enzyme activity during purification, activity ratios (activity at $\mathrm{pH} 7.4$ / activity at $\mathrm{pH} 8.8$ ) were compared using the rainbow trout enzyme. The ratios calculated for the crude extract without acetone treatment, with acetone treatment, and that for the purified enzyme were $1.9,2.0$, and 1.8 , respectively, inferring that no modification of enzyme occurred during the purification steps.
The effect of substrate concentration on the activity was measured in a range of 1-100 $\mu \mathrm{M}$ FBP at pH 7.5 and $25^{\circ} \mathrm{C}$. Fig. 2 shows Lineweaver-Burk plots obtained from the initial velocities of the enzyme reaction. The $\mathrm{Km}$ values differred among the three fish species examined: $5.6 \mu \mathrm{M}$ for rainbow trout, $8.2 \mu \mathrm{M}$ for eel, and $12.5 \mu \mathrm{M}$ for carp. These values agree with those of the rat FBPase. ${ }^{2,17)}$ However, Behrisch and Hochackha ${ }^{19)}$ determined the $\mathrm{Km}$ value of the rainbow trout enzyme to be ten-fold higher than the value in the present study. The reason of such discrepancy in the $\mathrm{Km}$ values of the rainbow trout enzyme is not clear. Fish FBPase showed the maximal activity at a FBP concentration range from 20 to $30 \mu \mathrm{M}$, beyond which the activity decreased with increasing concentration (Fig. 2). At $100 \mu \mathrm{M}$ FBP, the activities of the rainbow trout, eel, and carp enzymes were depressed by 35,25 , and $16 \%$ of their maximal activities, respectively. A number of workers have noted the same inhibitory effect of excessive FBP on FBPase activity. ${ }^{2,10-12)}$

The effect of several divalent metal ions at $5 \mathrm{mM}$ was examined using their chloride salts. Like all FBPase reported to date, three fish enzymes tested here required divalent cations such

Table 2. Effect of divalent metal ions on the activity of fructose-1,6-bisphosphatese from fish liver at $\mathrm{pH} 7.5$

\begin{tabular}{cccc}
\hline $\begin{array}{c}\text { Metal } \\
\text { ion }\end{array}$ & \multicolumn{3}{c}{ Relative activity $(\%)^{*}$} \\
\cline { 2 - 4 }$(5 \mathrm{~mm})$ & Rainbow trout & Eel & Carp \\
\hline None & 0 & 0 & 0 \\
$\mathrm{Mg}^{2+}$ & 100 & 100 & 100 \\
$\mathrm{Mn}^{2+}$ & 41 & 27 & 141 \\
$\mathrm{Co}^{2+}$ & 10 & 10 & 14 \\
$\mathrm{Ca}^{2+}$ & 0 & 0 & 0 \\
\hline
\end{tabular}

* Activity in the presence of $\mathrm{Mg}^{2+}$ was taken as $100 \%$
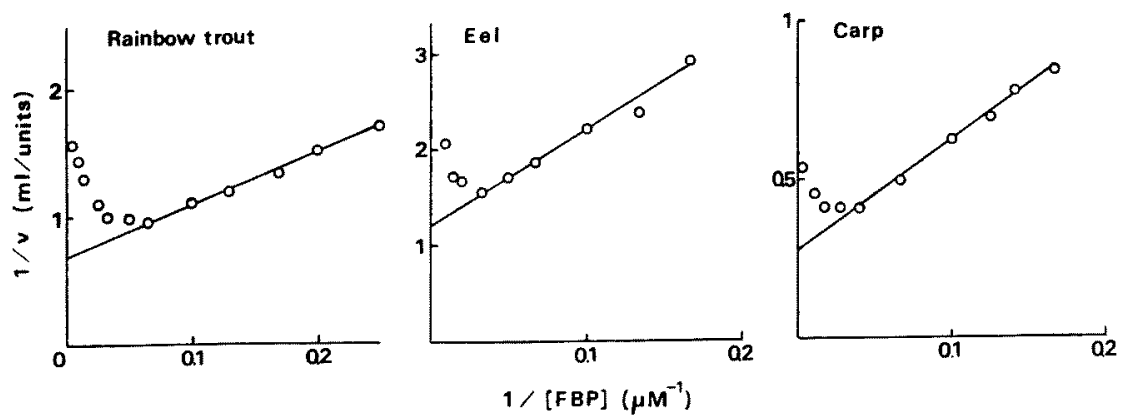

Fig. 2. Lineweaver-Burk plots of fructose-1, 6-bisphosphatase for fructose-1, 6-bisphosphate. The activity was measured in the presence of $5 \mathrm{mM} \mathrm{Mg} \mathrm{Mg}^{\star+}$ at $25^{\circ} \mathrm{C}$ in $50 \mathrm{~mm}$ Tris- $\mathrm{HCl}$ buffer (pH 7.5). 

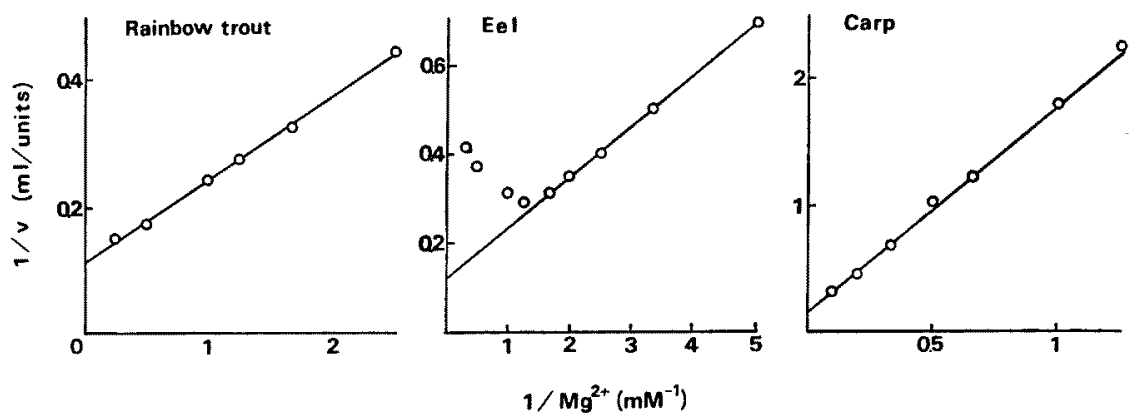

Fig. 3. Lineweaver-Burk plots of fructose-1, 6-bisphosphatase for $\mathrm{Mg}^{\mathrm{2}}$.

The activity was measured in the presence of of $0.03 \mathrm{mM} \mathrm{FBP}$ at $\mathrm{pH} 7.5$ and $25^{\circ} \mathrm{C}$.
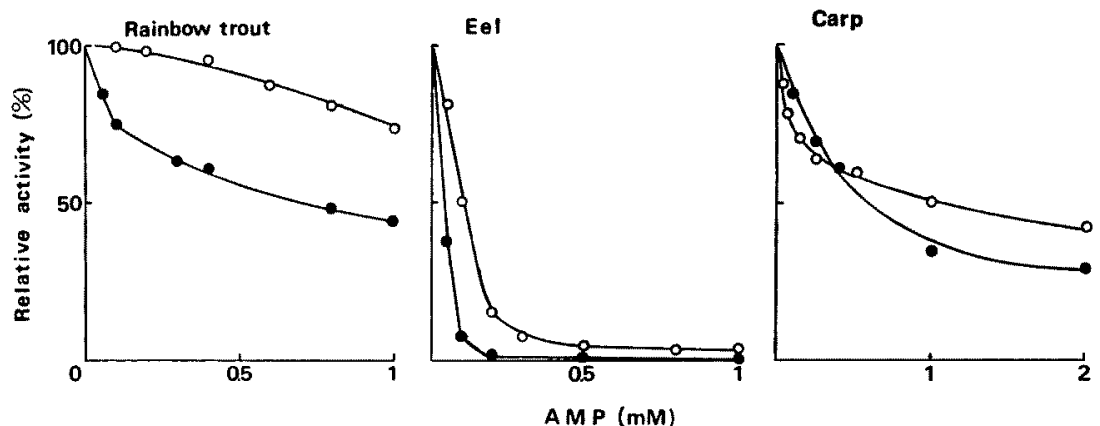

Fig. 4. Effect of AMP on the fructose-1,6-bisphosphatase activity from fish livers.

The activity was measured in the presence of $0.2 \mathrm{mM} F B P$ at $\mathrm{pH} 7.5$ and $25^{\circ} \mathrm{C}$; in the presence of $0.5 \mathrm{mM} \mathrm{Mg}^{2+}(-\mathrm{O}-)$ and $2.5 \mathrm{mM} \mathrm{Mg}^{2+}(--)$.

Table 3. Effect of monovalent metal ions on the activity of fructose-1, 6-bisphosphatese from fish liver at $\mathrm{pH} 7.5$

\begin{tabular}{lccr}
\hline \hline \multirow{2}{*}{$\begin{array}{c}\text { Metal } \\
\text { ion } \\
(150 \mathrm{mM})\end{array}$} & \multicolumn{3}{c}{ Relative activity $(\%)^{*}$} \\
\cline { 2 - 4 } & Rainbow trout & Eel & Carp \\
\hline None & 100 & 100 & 100 \\
$\mathrm{~K}^{+}$ & 161 & 124 & 82 \\
$\mathrm{NH}_{4}^{+}$ & 184 & 127 & 41 \\
$\mathrm{Na}^{+}$ & 90 & 45 & 63 \\
\hline
\end{tabular}

* Activity was measured in the presence of $5 \mathrm{~mm} \mathrm{Mg}^{2+}$, and the value in the absence of monovalent metal ion was taken as $100 \%$.

as $\mathrm{Mg}^{2+}$ for activation of the enzyme (Table 2). In the presence of $5 \mathrm{mM} \mathrm{Mn} \mathrm{Mn}^{2+}, 27-41 \%$ of the activity in the presence of $\mathrm{Mg}^{2+}$ was detected in rainbow trout and eel, whereas $141 \%$ in carp. $\mathrm{Co}^{2+}$ exhibited a slight effect on the activity (10$14 \%$ ). $\mathrm{Ca}^{2+}$ showed no effect on the activation of fish FBPase. Likewise, the activities of rainbow trout ${ }^{102}$ and salmon ${ }^{12)}$ enzymes were not activated by $\mathrm{Ca}^{2+}$. From the Linewevaer-Burk plots (Fig. 3), the $\mathrm{Km}$ values for $\mathrm{Mg}^{2+}$ were calculated to be $1.3 \mathrm{~mm}$ for rainbow tronut, 0.95 $\mathrm{mm}$ for eel, and $10 \mathrm{~mm}$ for carp, respectively. The calculated $\mathrm{Km}$ values for $\mathrm{Mn}^{2+}$ ranged from 0.15 to $0.33 \mathrm{~mm}$ (data not shown). Shimeno ${ }^{14)}$ demonstrated that FBPase from the spotted mackerel was activated by $\mathrm{Mg}^{2+}$, and the optimal concentration for the activation was $5 \mathrm{~mm}$. He also observed that the activity in the presence of $5 \mathrm{~mm}$ $\mathrm{Ca}^{2+}$ was one eighth that in the presence of $5 \mathrm{~mm}$ $\mathrm{Mg}^{2+}$.

Underwood and Newsholme ${ }^{17)}$ showed that the effect of divalent metal ions on the FBPase activity was affected in the presence of the chelating compounds or monovalent metal ions. The effect of monovalent metal ions on the FBPase activity was examined in the presence of $5 \mathrm{mM} \mathrm{Mg}^{2+}$. As shown in Table 3, monovalent cations (150 mM) such as $\mathrm{K}^{+}$and $\mathrm{NH}_{4}{ }^{+}$in the presence of $5 \mathrm{mM}$ $\mathrm{Mg}^{2+}$ further activated the rainbow trout and eel enzymes ranging from 24 to $84 \%$. In contrast, the activity of carp enzyme decreased by $18 \%$ with $\mathrm{K}^{+}$and $59 \%$ with $\mathrm{NH}_{4}{ }^{+}$respectively. $\mathrm{Na}^{+}$ decreased the activities of three fish enzymes by 
$10-55 \%$. Tol et al.$^{\text {8) }}$ noted that the activity of the rabbit muscle enzyme was increased 2-3 times in the presence of $0.1 \mathrm{M} \mathrm{K}^{+}$or $\mathrm{NH}_{4}{ }^{+}$, while decreased the activity.

AMP is a specific, allowsteric inhibitor of FBPase. ${ }^{2)}$ As shown in Fig. 4, fish FBPase was inhibited by AMP and the degree of inhibition varied according to the $\mathrm{Mg}^{2+}$ concentration. In the presence of $0.5 \mathrm{mM} \mathrm{Mg}^{2+}$ and $1 \mathrm{mM} \mathrm{AMP}$ at $\mathrm{pH} 7.5$ the activities of the rainbow trout, eel, and carp enzymes were inhibited by 57, 100, $65 \%$, respectively. Increasing the $\mathrm{Mg}^{2+}$ concentration to $2.5 \mathrm{~mm}$, however, resulted in the weakening of inhibition, particularly in the case of the rainbow trout enzyme. This agree with the observation of Behrisch and Hochachka ${ }^{103}$ in rainbow trout. They noted that FBPase inhibition by AMP was affected by the $\mathrm{Mg}^{2+}$ concentration, along with reaction temperature and $\mathrm{pH}$.

\section{Acknowledgement}

The present study was funded in part by a Grant-in-Aid for Scientific Research form the Ministry of Education, Science and Culture.

\section{References}

1) S. J. Benkovic and M. M. deMaine: in "Ad" vances in Enzymol."' (ed. by A. Meister), Vol. 53, Academic Press, New York, 1982, pp. 45-82.

2) K. Taketa and B. M. Pogell: J. Biol. Chem.,
240, 651-661 (1965).

3) T. P. Olson and R. R. Marquardt: Biochim. Biophys. Acta, 268, 453-467 (1972).

4) S. Pontremoli: in "Methods in Enzymol." (ed. by W. A. Wood), Vol. 9, Academic Press, New York, 1966, pp. 625-631.

5) A. M. Geller and W. L. Byrne: in "Methods in Enzymol." (ed. by W. A. Wood), Vol. 42, Academic Press, New York, 1975, pp. 272-276.

6) S. Pontremoli and E. Melloni: in "Methods in Enzymol.", Vol. 42, Academic Press, New York, 1975 , pp. 354-359.

7) M. Enser, S. Shapiro, and B. L. Horecker: Arch. Biochem. Biophys., 129, 377-383 (1969).

8) Y. Tashima, G. Tholy, G. Drummond, H. Bertrand, J.S. Rosenberg, and B. L. Horecker: Arch. Biochem. Biophys., 149, 118-126 (1972).

9) A. V. Tol, W. J. Black, and B. L. Horecker: Arch. Biochem. Biophys., 151, 591-596 (1972).

10) H. W. Behrisch and P. W. Hochachka: Biochem. $J .$, 111, 287-295 (1969).

11) H.W. Behrisch and P. W. Hochachka; Biochem. J., 112, 601-607 (1969).

12) H. W. Behrisch: Biochem. J. 115, 678-696 (1969).

13) A. M. Gonzalez, F. Gonzalez, S. Golf, and F. Marcus: J. Biol. Chem., 247, 6067-6070 (1972).

14) S. Shimeno: Mem. Fac. Kochi Univ., 2, 1-107 (1974).

15) K. Nagashima, T. Nakagawa, and F. Nagayama: Nippon Suisan Gakkaishi, 55, 897-903 (1989).

16) K. Nakashima and B. L. Horecker: Arch. Biochem. Biophys., 146, 153-160 (1971).

17) A. H. Underwood and E. A. Newsholme: Biochem. J., 95, 767-774 (1965). 